\title{
China's Growing Presence in Brazil and Latin America
}

\author{
Luiz Augusto de Castro Neves and Tulio Cariello
}

\begin{abstract}
The 21st Century opened a new chapter for the relations between China and Latin America. As of 2020, Brazil has received more than half of all Chinese investment in Latin America-around USD 66 billion with three fourths of that investment dedicated to the energy sector and the rest going to agriculture, infrastructure and other areas. While Chinese foreign investment has declined in recent years due to the pandemic, China's recovery will likely also reach Brazil with new opportunities for investment and cooperation.
\end{abstract}

Keywords China and Latin America $\cdot$ Energy sector $\cdot$ Chinese foreign investment

The twenty-first century opened a new chapter for the relations between China and Latin America, characterized by an increasingly evident presence of Chinese investments in the region. Bilateral trade, which had been consistently expanding since the 1990s, already showed the complementarity between the two economies, with significant flows of commodities (minerals, oil and gas and agribusiness products) to China, in exchange for industrial products and inputs.

Following the outflow of Chinese business, which began in parallel with Beijing's entry to the WTO in 2001, Latin America was targeted by China as a potential destination for new ventures. The region received around USD 115 billion in investments between 2007 and 2018, with a large-scale concentration in sectors well established in the bilateral trade, such as the exploration of natural resources, energy and agriculture.

As of 2020, Brazil has received more than half of all Chinese investment in Latin America-around USD 66 billion, according to the Brazil-China Business Council (CEBC). Three-fourths of that investment was dedicated to the energy sector and dominated by central state-owned Chinese enterprises, such as State Grid, China Three Gorges, Sinopec, CNPC and CNOOC. Even with that substantial concentration in electricity and oil exploration, China also invested in other sectors, including mining, infrastructure, agriculture, industry and information technology, with major Chinese banks including the Industrial and Commercial Bank of China, the China Construction Bank and the Bank of China also setting up operations in Brazil.

L. A. de Castro Neves $(\varangle) \cdot$ T. Cariello

Brazil-China Business Council, Rio de Janeiro, Brazil

(C) The Author(s) 2022

H. Wang and L. Miao (eds.), Transition and Opportunity, China and Globalization, https://doi.org/10.1007/978-981-16-8603-0_8 
However, Brazilian investment in China is very limited by comparison. Despite the fact that China is the main destination for Brazilian exports (around 32\% of the country's exports), Brazilian businesses have so far been very hesitant to take advantage of the numerous opportunities offered by the Chinese market. One can, therefore, observe a great asymmetry between the two partners as far as investments are concerned.

The promising scenario for Chinese investments in Brazil and the rest of Latin America is, however, facing a few obstacles, including several geopolitical challenges caused by a resurgence in nationalism, the China-US dispute and COVID-19. The pandemic crisis caused a dramatic fall in foreign direct investment (FDI) in 2020. Global FDI flows dropped by 35\% to USD 1 trillion, from USD 1.5 trillion in 2019. This is almost $20 \%$ below the 2009 fall after the global financial crisis.

China has been very careful in terms of foreign investment, particularly after its record outflow of capital in 2016. It also suffered the consequences of this challenging global picture, with a series of drops in the value of its non-financial investment abroad since 2017. Like other relevant partners of China in the international system, Brazil was not immune to this crisis and faced a $74 \%$ fall in the value of its investments at home in 2020 .

\section{Chinese Investments in Latin America and the Caribbean}

In 2015, during the China-CELAC Forum (Community of Latin American and Caribbean States), President Xi Jinping said China would invest approximately USD 250 billion in the region within the next decade. Indeed, between 2007 and 2018, China invested about USD 115 billion in Latin America and the Caribbean, according to the data from China Global Investment Tracker (CGIT).

However, despite this rhetoric, China's investments in Latin America and the Caribbean declined sharply between 2017 and 2018. Indeed, data compiled by Boston University's Global Development Policy Center (GDP Center) ${ }^{1}$ show a $58 \%$ yearon-year decrease - the largest drop in investments since 2010-with special notice paid to the irregular intensity of the decrease in investments in the region during this period, as shown in the following chart (Fig. 1).

In this context, data from the GDP Center survey also shows that this decrease in investments from 2017 to 2018 was equally reflected in the main forms of Chinese investment in Latin America and the Caribbean. Greenfield investments decreased by $64 \%$, from USD 4.4 billion to USD 1.6 billion while China's mergers and acquisitions in the region decreased 57\%, from a record USD 17.5 billion in 2017 to USD 7.6 billion in 2018 .

More recent data collected by CGIT referring specifically to South America confirm that Chinese investments have followed an irregular pattern since 2010,

\footnotetext{
${ }^{1}$ Chinese investments compiled from sources mentioned include Hong Kong, Taiwan, and Macao.
} 


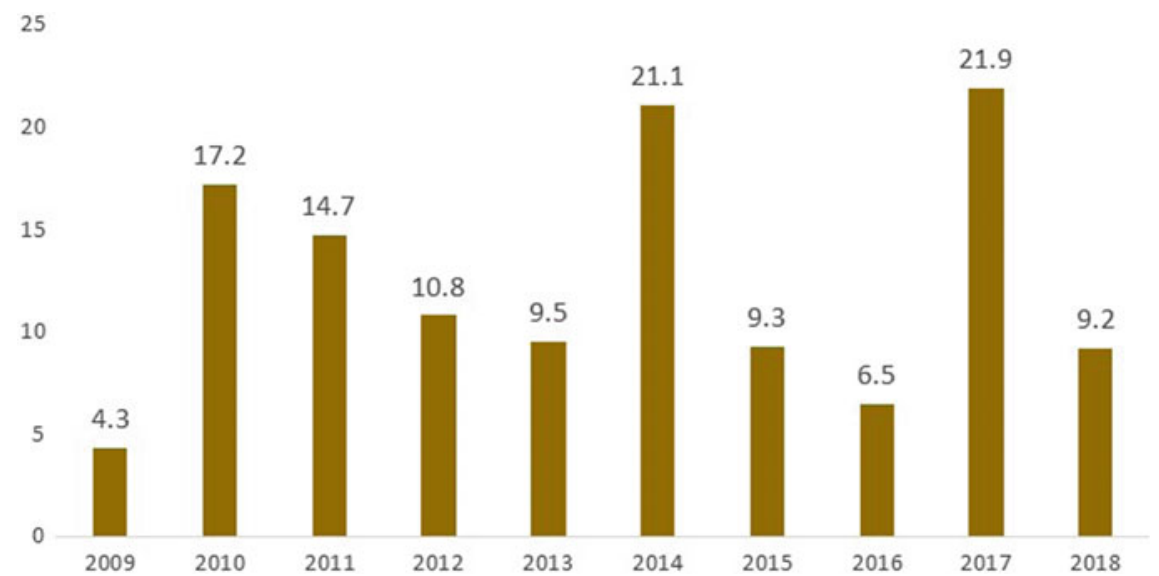

Fig. 1 Flow of Chinese Investments in Latin America and the Caribbean I 2010-2018 (USD billion). Sources DeaLogic and Financial Times, by the GDP Center-Boston Universityl Prepared by: CEBC

with an almost uninterrupted decline between 2016 and 2020 and growth verified only between 2017 and 2018 .

Even as China reduces its appetite for investments overseas, independent sources indicate that Brazil continues to be the evident center of gravity for Chinese investments in Latin America and the Caribbean. According to the chart above, practically half of all Chinese investments in the region between 2007 and 2018 were directed towards Brazil, a considerably higher percentage than in Peru, which comes in second place with $19 \%$ of the total (Fig. 2).

Similarly, data compiled by the Latin America and the Caribbean Network on China (Red LAC-China) confirm that the largest recipients of Chinese investments in the region are still Brazil and Peru, with USD 48.5 billion and USD 15.7, respectively.

\subsection{Sector Analysis of Chinese Investments in Latin America and the Caribbean}

From a sectorial point of view, Chinese investments in Latin America and the Caribbean between 2007 and 2018 were mostly directed towards the energy sector (particularly hydroelectricity and oil), which accounted for 53\% of investments in the region. Mining accounted for $30 \%$ of total investments, followed by agriculture $(5 \%)$, transportation (4\%), finance (3\%), and chemicals (2\%).

Brazil attracted seven of the ten largest energy investments in the region between 2007 and 2018, while Argentina attracted two projects and Peru one, as can be seen in Table 1. 


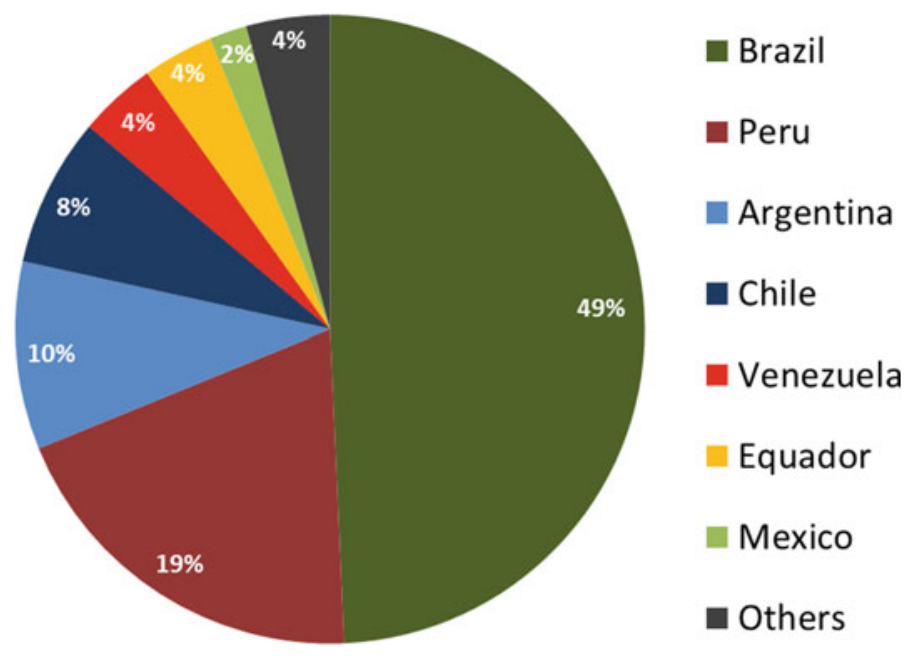

Fig. 2 Chinese Investment Stock in Latin America and the Caribbean, Selected Countries (By Value, USD) I 2007-2018. Source China Global Investment Tracker I Prepared by: CEBC

Table 1 Major Chinese Energy Investments in Latin America and the Caribbean I 2007-2018

\begin{tabular}{l|l|l|l|l}
\hline Year & Investor & $\begin{array}{l}\text { Investment } \\
\text { partner/recipient }\end{array}$ & Recipient country & $\begin{array}{l}\text { Investment value } \\
\text { (US\$ billion) }\end{array}$ \\
\hline 2010 & Sinopec & Repsol & Brazil & 7.1 \\
\hline 2016 & State grid & CPFL & Brazil & 4.91 \\
\hline 2011 & Sinopec & Galp energia & Brazil & 4.8 \\
\hline 2016 & Three gorges & - & Brazil & 3.66 \\
\hline 2017 & State grid & CPFL & Brazil & 3.44 \\
\hline 2010 & CNOOC & Bridas & Argentina & 3.1 \\
\hline 2010 & Sinochem & Statoil & Brazil & 3.07 \\
\hline 2013 & CNPC & Petrobras & Peru & 2.89 \\
\hline 2010 & Sinopec & $\begin{array}{l}\text { Occidental } \\
\text { petroleum }\end{array}$ & Argentina & 2.47 \\
\hline 2017 & $\begin{array}{l}\text { State power } \\
\text { investment }\end{array}$ & & Brazil & 2.26 \\
\hline
\end{tabular}

Source China Global. Investment Tracker I Prepared by: CEBC

However, given that Brazil received almost half of all Chinese investments in the region during that period, and considering that the energy sector strongly influences overall investments in the country, it is important to observe that the overall framework of Chinese investments in Latin America and the Caribbean would change significantly if we were to ignore the investments in Brazil. 
When we ignore investments in Brazil, we see that the energy sector continues to be a relevant sector, accounting for $36 \%$ of total investments. However, the mining segment is clearly the sector that has attracted the most interest from Chinese investors in recent years. The mining industry accounted for $51 \%$ of the investments (in total value) between 2007 and 2018. There were particularly large investments made during this period, such as the purchase of the Las Bambas copper mine in Peru by a consortium including China Minmetals, Guoxin International, and CITIC together with Glencore. The total value of the transaction was approximately USD 10 billion, one of China's largest overseas acquisitions in the mining sector. The mining and energy sectors are followed by investments in agriculture (4\%), transports (3\%) and other industries $(6 \%)$ with little relevance in terms of individual participation.

When we look at investments in mining for all of the Latin American and Caribbean countries included in the China Global Investment Tracker, it is clear that Peru was the country that attracted the majority of China's investments in the region, having received $54 \%$ of all investments made in this sector. Chile comes next having received $18 \%$ of the investments, while Brazil received $12 \%$ and Ecuador $11 \%$.

As the following table shows, Peru attracted five of the 10 largest investments in the region, while Chile and Brazil received investments for two projects each, and Ecuador one (Table 2).

Table 2 Major Chinese Investments in the Mining Industry in Latin America and the Caribbean I 2007-2018

\begin{tabular}{|c|c|c|c|c|}
\hline Year & Investor & $\begin{array}{l}\text { Investment } \\
\text { partner/recipient }\end{array}$ & Recipient country & $\begin{array}{l}\text { Investment value } \\
\text { (USD billion) }\end{array}$ \\
\hline 2014 & $\begin{array}{l}\text { Minmetals, Suzhou } \\
\text { Guoxin, and CITIC }\end{array}$ & Glencore & Peru & 6.99 \\
\hline 2018 & Chengdu Tianqi & $\begin{array}{l}\text { Sociedad quimica } \\
\text { y minera }\end{array}$ & Chile & 4.07 \\
\hline 2010 & $\begin{array}{l}\text { Minmetals, Suzhou } \\
\text { Guoxin, and CITIC }\end{array}$ & - & Peru & 2.5 \\
\hline 2018 & Zhongrong Xinda & Pampa de pongo & Peru & 2.36 \\
\hline 2008 & Chinalco & - & Peru & 2.16 \\
\hline 2014 & $\begin{array}{l}\text { China Railway } \\
\text { construction and } \\
\text { China nonferrous }\end{array}$ & Mirador & Wquador & 2.04 \\
\hline 2011 & $\begin{array}{l}\text { Taiyuan iron, } \\
\text { CITIC, baosteel }\end{array}$ & CBMM & Brazil & 1.95 \\
\hline 2010 & $\begin{array}{l}\text { Shunde rixin and } \\
\text { minmetals }\end{array}$ & - & Chile & Jan-00 \\
\hline 2018 & Chinalco & - & Peru & 1.3 \\
\hline 2010 & $\begin{array}{l}\text { Development } \\
\text { bureau (Jiangsu) }\end{array}$ & $\begin{array}{l}\text { Bernardo de mello } \\
\text { itaminas }\end{array}$ & Brazil & 1.2 \\
\hline
\end{tabular}

Source China Global Investment Tracker I Prepared by: CEBC 


\section{Chinese Investments in Brazil}

The international expansion of Chinese firms, already mentioned above, also takes into account a geopolitical variable, which, at least as far as South America is concerned, cannot be ignored. In this context, Brazil becomes a sort of focal point in the region. Recent history has been dominated by the overwhelming influence of the United States in the region, particularly during the Cold War. With the relative dilution of ideological tensions, new issues have appeared in American foreign policy, such as terrorism, immigration and the emergence of China and its multiple impacts on international relations. This has led, to a certain extent, to a relative reduction of the region's priority in American foreign policy. The relative distancing has facilitated the creation of space for China in the region, taking into account the fact that China was already engaged in expanding its presence in the world.

The first decade of the twenty-first century brought about a new trend to the relationship between China and Brazil. Their agenda became much more complex, with the explosion of bilateral trade and the growing relevance of Chinese investment within their bilateral relationship.

In the commercial sector the prevailing development model in China in the 2000s generated a big window of opportunity for Brazil and stressed the complementarity of both economies, which led to an almost uninterrupted period of growth in bilateral trade, very often driven by Brazilian exports of iron ore, soybeans and crude oil.

In 2009, China overtook the United States to become Brazil's main export destination, which has remained the case to the present day. The expansion of sales to China was very significant and reached USD 67.7 billion in 2020, making up a third of all Brazilian exports. Total trade between the two countries reached a record USD 101 billion, the first time Brazil's foreign trade reached a three-digit figure with a single country. (Fig. 3)

According to the Brazil-China Business Council (CEBC), between 2007 and 2020, 130 Chinese firms announced 242 projects in Brazil, which resulted in investments

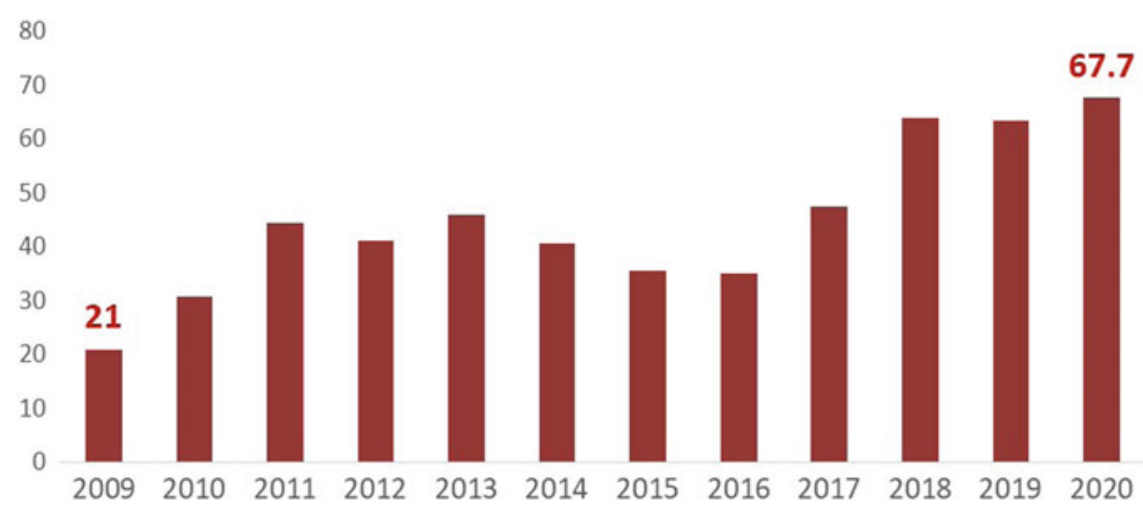

Fig. 3 Brazilian Exports to China (USD billion). Source Ministry of Economy I Prepared by: CEBC 
potentially amounting to USD 110.7 billion. Of these, 177 projects were actually implemented, expanding the stock of Chinese investment in Brazil to USD 66.1 billion. The China Global Investment Tracker, which only measures investments over USD 100 million, estimates that stock to be USD 60.6 billion, not very different from the CEBC figure. Considering the global context, available data indicates that Brazil was the fifth-largest recipient of Chinese investment for the period between 2005 and 2020, immediately following the US, Australia, UK and Switzerland.

Between 2010 and 2019, according to the Ministry of the Economy of Brazil, China and the United States have traded places as the first and second-largest direct investors in the country. The cultural distance and problems related to the complexity of the Brazilian business environment, especially in the areas of taxation and regulation, have not, however, driven away Chinese investment. Over the past decade, China has invested more in Brazil than any other country historically, except the United States.

Due to their irregularity, those investment flows do not show a defined trend. The largest investment was in 2010 (USD 13 billion), which is considered by many the year Chinese business "discovered" Brazil, and China has continued to show interest in the Brazilian economy in several areas ever since.

After the initial euphoria, there was a downward trend until 2014, followed by a consistent increase between 2014 and 2017. Over the last three years, investment has varied as shown in the figure below. It should be noted that the year 2020 was a very atypical year due to the pandemic (Fig. 4).

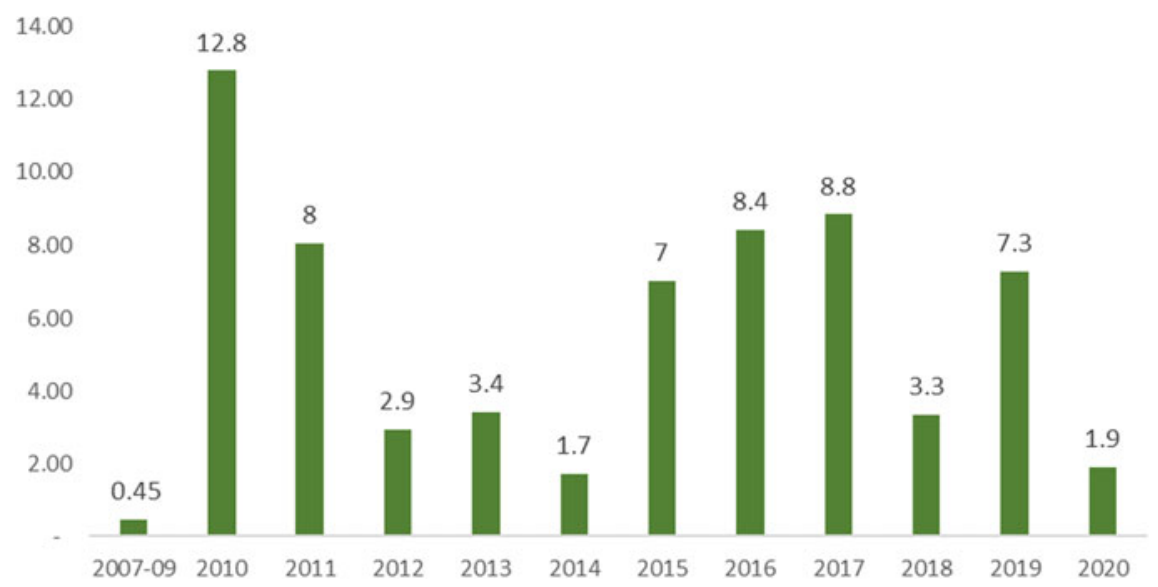

Fig. 4 Flow of Chinese Investments in Brazil (USD billion). Source CEBC 


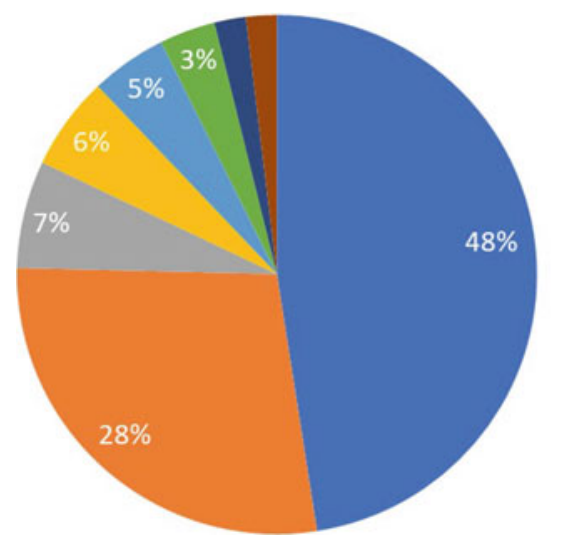

Electricity

- Oil and Natural Gas

Mining

Manufacturing Industry

Infrastructure

- Agriculture and Related Services

Financial Services (2\%)

Others (2\%)

Fig. 5 Business Sector Distribution of Chinese Investments in Brazil (By Value, USD) | 2007-2020. Source CEBC

Figure 5 shows the distribution of the Chinese investment in Brazil by business sector. The electricity sector makes up almost half of it-State Grid and China Three Gorges are leading investors and most of their assets abroad are in Brazil. The oil and gas sector is the second most important and Sinopec, CNPC, CNOOC and Sinochem are already established in Brazil. The third most important sector is mining, represented by Wuhan Iron and Steel (WISCO) and the participation of a consortium of Chinese companies (CITIC Group, Anshan Iron \& Steel, Shougang and Taiyuan Iron \& Steel) which holds $15 \%$ of CBMM, a Brazilian firm that explores niobium, among other activities. More recently, China Molybdenum Company, acquired the assets of Anglo-Americans. In the industrial sector, it is also worth mentioning the increased influence of Chinese firms such as BYD, Gree, Midea, Chery, Sany, XCMG and Liugong.

The Chinese have also invested in important infrastructure projects, particularly the presence of China Merchants Port, China Communications Construction Company and China Railway 20 Bureau Group.

The fact that $3 \%$ of the Chinese initiatives are in the agricultural sector, a value relatively low considering the sector's great potential, is also of note. Naturally, the complementary nature of the two countries in this area attracts Chinese business as Brazilian exports to Asia are heavily concentrated in agricultural products. According to official Brazilian data, agricultural exports to China jumped from $35 \%$ of total Brazilian exports to China in 2010 to $50 \%$ in 2020. COFCO, Tide Group and Long Ping High Tech have invested substantially in the Brazilian agricultural sector.

The growing Chinese presence in the Brazilian economy has also awakened the interest of the Chinese financial sector, which has gradually expanded operations in Brazil. The Bank of China was the first Chinese bank to be established in the country, beginning in 1998 with a representative office and ultimately becoming a full bank in 2009. 
From 2012 onwards other Chinese banks opened branches in Brazil, either directly or through the acquisition of local banks. It is worth mentioning the Industrial and Commercial Bank of China, the acquisition of Banco BBM by the Bank of Communications and of Bicbanco by the China Construction Bank. The acquisition of foreign banks with branches in Brazil also led to the presence of Chinese banks in Brazil, as was the case of Banco Espírito Santo de Investimento by Haitong.

The number of projects shows a diversified picture. Investment in the electricity sector remains the most relevant, corresponding to more than a third of the confirmed projects. Closely related is the increased participation in the industrial sector, which comes in second place making up $28 \%$ of all investments.

If expenditures are taken into consideration, instead of the number of projects, some sectors maintain their relevant positions in the overall picture of confirmed projects, as is the case with agriculture and oil extraction, each of which makes up $7 \%$, and financial services with $6 \%$. Also worth mentioning are the initiatives in the field of information technology, like the Didi Chuxing mobile transportation platform for urban mobility, which acquired the Brazilian ride-hailing firm 99, and Tencent, which invested in Nubank, the largest fintech company in Latin American.

\section{Brazilian Investment in China}

Brazilian investment in China is much more modest than Chinese investment in Brazil. This situation can be mainly explained by the difficulty among Brazilians to adapt to cultural and consumer factors in the Chinese market and the relative openness of Brazil to receive foreign brands. One should add the Chinese ability to adapt to foreign markets which is a result of their "going out" strategy, practiced by the Chinese government since 2000. It is a reality that most Brazilian firms do not have a strategic agenda for "going out" with the goal of establishing their brands in the global market.

The limited Brazilian presence in China has not changed in recent years. According to data from Brazil's Central Bank, between 2007 and 2015, Brazilian businesses invested USD 291 million in China, the equivalent of less than $1 \%$ of total foreign investment in China. However, Chinese official data (MOFCOM) indicates that over the same period cumulative Brazilian investment in China reached USD 508 million, but it should be noted that a portion of the investment between the two countries may not appear in official data due to distortions in the registration of inflows and outflows of capital, which are very often accounted as originating in third countries.

The modest numbers of Brazilian investment in China reveal that Brazilian business has been relatively indifferent vis-à-vis the transformations that have made China one of the largest and dynamic consumer markets in the world, as well as an important innovator.

The Brazil-China Business Council has records of 84 Brazilian firms present in China in terms of, inter alia, production units, representative offices or branches. 
Fig. 6 Distribution of Brazilian Companies in China by Performance Profile. Source CEBC, Brazil-China Forum

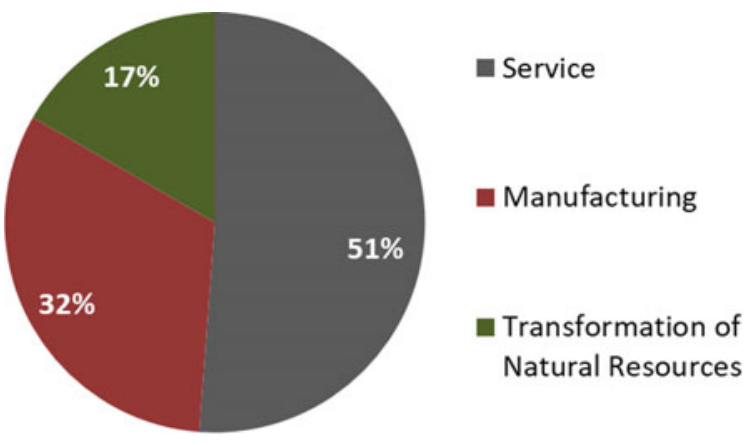

These companies can be divided into three general areas in terms of their business activities: services providers, manufacturers and natural resources processors, as shown in Fig. 6.

Business activities carried out by Brazilian firms in China include consulting, sourcing, distribution and sales, trading, industrial production, financial services, representation, market research, natural resources extraction and marketing. Consulting services, trading, distribution and sales, and sourcing account for around $70 \%$ of total business volume, which is proof that the role of Brazilian business in China has been relatively limited.

\subsection{Where Brazilian Firms Are Located in China}

Most Brazilian companies are located in the country's coastal regions and nearby provinces, attracted by special economic zones, most of which are located in these areas and are the main centers of foreign investment. They also enjoy advantages in terms of infrastructure and qualified labor due to their proximity to main urban centers and business hubs.

\section{The Evolution of Chinese Investments Abroad}

From the beginning of the twenty-first century, China officially began promoting the global expansion of Chinese enterprises. In 2001, when China became a member of the WTO, the then Prime Minister Zhu Rongji declared that the Chinese government should implement a "going out" strategy, encouraging enterprises that had comparative advantages to invest abroad, focusing on exploring natural resources with local partners, participating in engineering projects and increasing the presence of Chinese labor internationally. The Chinese leadership was also seeking to create favorable 
conditions for the establishment of Chinese firms abroad while recognizing the need to supervise these investments to avoid the loss of state assets.

Starting in 2003, with the government's blessing, Chinese investment abroad began a new process of stable growth. By 2015, the value of non-financial investments increased for 13 consecutive years, with an average growth of $33.6 \%$ year-onyear. The motivations for the capital outflow gradually diversified, searching for new consumer markets, which included the expansion of lines of production abroad, the acquisition of competitive brands and the acquiring of new technologies. Likewise, Chinese investments also experienced greater diversification in the way they entered other countries, which included greenfield projects, mergers and acquisitions, and joint ventures.

After years of fast growth, non-financial Chinese investments abroad set a record in 2016 of USD 170.11 billion, $44.1 \%$ more than the previous year, for projects with 7,961 enterprises in 164 countries and regions. It was the first time Chinese outbound investment flows surpassed foreign investments in China.

The euphoria that led to the Chinese capital outflow in 2016 generated concern among the country's authorities, who saw what they perceived to be a massive capital flight for risky investments abroad. In November 2016 the Chinese government strengthened its controls over investment abroad and, in August 2017, the National Development and Reform Commission set up regulations for the approval of those investments.

These measures led to a decrease in Chinese investment abroad for the first time in decades. In 2017, Chinese foreign investment fell $29.4 \%$ to USD 120.1 billion. Likewise, the number of foreign firms with Chinese participation decreased to 6,236, $22 \%$ fewer than in the previous year. Beijing also pressured Chinese companies to sell their assets abroad, diminishing their global presence. What's more, the government also reduced the liquidity in the financial system, which limited the availability of financing sources to invest abroad (Fig. 7).

In this context, mergers and acquisitions by Chinese firms abroad were particularly affected. In 2016, China participated in 724 projects, amounting to USD 107 billion. In the following year, the number of projects fell to 341 with a value of USD 96 billion, a decline of $53 \%$ in the number of projects and $10 \%$ in terms of value. There was also a decrease of $33 \%$ in the number of countries and regions where China had operations, dropping from 73 to 49. In 2018, China's MOFCOM declared that "irrational investments" had been effectively contained.

After 2017, Chinese investments abroad started to stagnate and fall. According to MOFCOM, non-financial investments were kept around USD 120 billion, with a marginal growth of $0.3 \%$. In the following year, they fell $8.2 \%$, to USD 110 billion, and maintained roughly the same value in 2020 with a small decrease of $0.4 \%$. A study presented by UNCTAD in 2020 shows a similar trend.

The new restrictions imposed by the central government were indeed effective in the decline in Chinese investments abroad, but they were not the only factor. The geopolitical environment and the Covid-19 pandemic also played an important role. The "trade war" between the United States and China, initiated by then President Donald Trump in 2018, brought about a more comprehensive dispute between the 


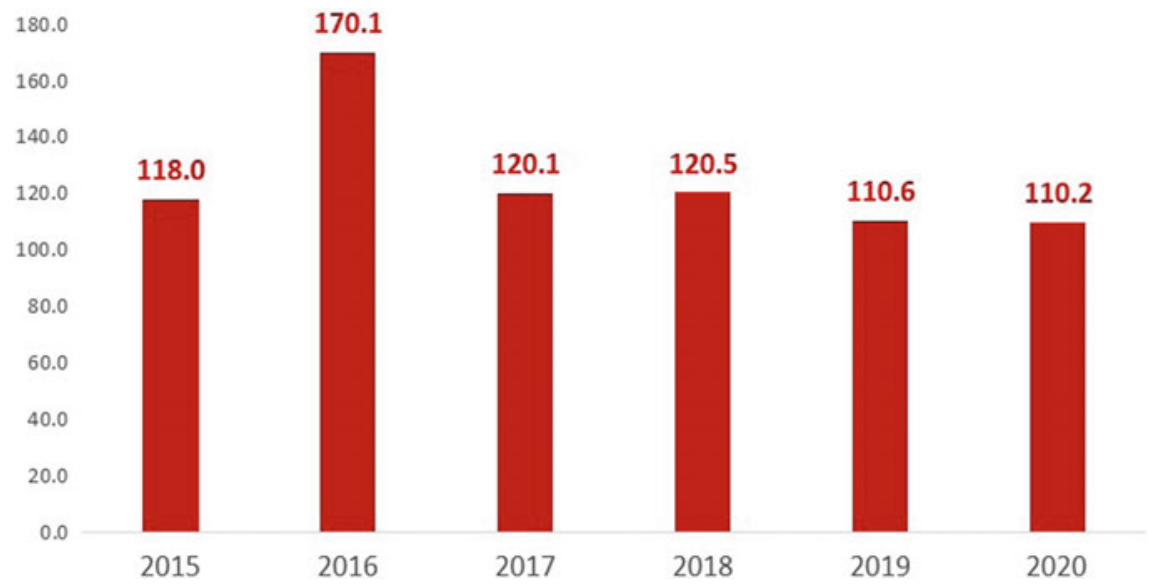

Fig. 7 Chinese non-Financial Investments Abroad (USD billion). Source MOFCOM

two powers, focusing on issues like new technologies and the battle for influence in the international system. In terms of investment, Washington also restricted access of Chinese firms to the US market, a move that has been followed by some of China's important economic partners, such as Australia and European countries.

\subsection{The Pandemic and Changes in the Direction of Investment Flows}

While we can say Chinese investment abroad has stagnated in recent years, we cannot say the same about foreign investment in China. In the midst of the pandemic and a reduction of $35 \%$ in global foreign investment in 2020, foreign investment in China increased 5.7\% compared with 2019, totaling USD 149 billion, with notable increases in the pharmaceutical and information technology sectors. In 2020, China approached the United States, which maintained its leadership in attracting foreign investment with USD 156 billion in investment, also saw the value of these transactions decrease $40 \%$ in their territory (Fig. 8).

Part of this success can be attributed to the strategy adopted by the Chinese government, which gave priority to domestic growth in order to combat the economic pressure of the pandemic, which included strict sanitary controls and stimuli to attract foreign investment.

With the goal of attracting foreign businesses, MOFCOM and the NDRC have updated two lists_- "negative lists"-in which foreign participation is either restricted or prohibited. The new lists, which came into effect in July 2020, have greatly reduced restrictions in sectors such as finance, infrastructure, transportation, agriculture, manufacturing, pharmaceuticals and R\&D. 


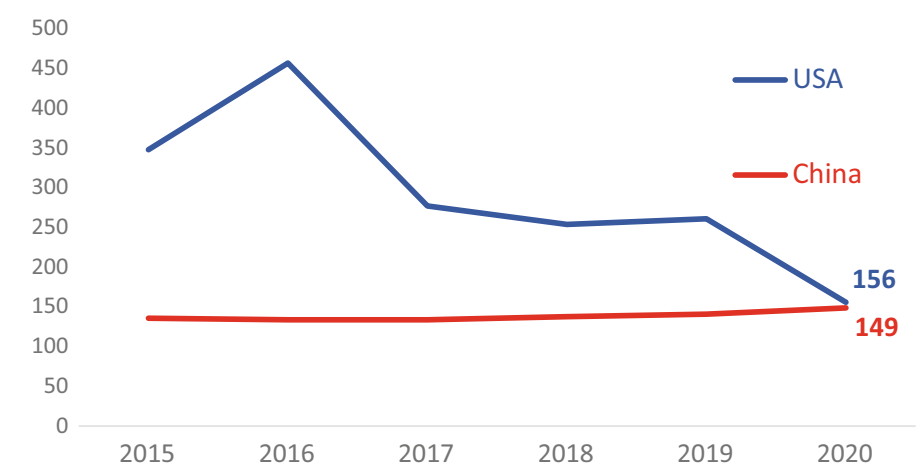

Fig. 8 FDI Inflows in China and the United States (USD billion). Source UNCTAD

The proposals for the 14th Five-Year Plan, published at the end of 2020, have shown the continuity of this trend. The "dual circulation" strategy announced by the Chinese government, in which internal and external markets support each other, includes objectives such as stimulating domestic demand, increasing productivity for export while at the same time improving the conditions for foreign investment in China, especially in innovative and high-tech sectors. This strategy, however, does not mean that China will become more introverted. As far as we can see, China's strategic goal is to make it less vulnerable to international economic shocks like the one provoked by the pandemic and restrictions imposed by the US in the technological sector.

\section{Conclusion}

A number of factors have created new challenges for China's globalization, which is reflected in the relative decline of Chinese investments in some parts of the world. Some of these factors include the Chinese government's increased control over capital outflows, China's commercial and technological dispute with the United States and the COVID-19 pandemic. Beijing's "dual circulation" strategy may also change the focus of Chinese investment abroad, focusing on quality over quantity and prioritizing the role of strategic sectors in China's development. It is also expected that further opening of the Chinese market to foreign investment in key areas like high-tech is not too far off.

Despite the recent decline of Chinese investment around the world, President Xi Jinping confirmed at the 2015 China-CELAC meeting that China would invest about USD 250 billion in Latin America and the Caribbean in the next decade, which indicates that the region will continue to attract Chinese interest. Brazil, having received about half of Chinese investment in Latin America and the Caribbean to 
date, is an obvious center of gravity for investment in the region, and the country will continue to influence Beijing's foreign policy in Latin America.

This analysis of Chinese investment in Brazil demonstrates a long-term interest. Most of China's investments, particularly in infrastructure, take a long time to mature, which indicates that China plans on remaining in Brazil for several years and will establish a solid presence in the Brazilian economy. One consequence that is already being felt in Brazil is a palpable increase in the overall productivity of the Brazilian economy, which is vital for the expansion of the Brazilian exports, not only to China, but to the rest of the world. This expansion is a fundamental prerequisite for the Brazilian economy to resume growth. China's economy will also probably continue to grow far beyond the world average, which means that China could be a fundamental part of continued economic growth in Brazil.

In this sense, there is room for Brazil — and also Latin America - to attract Chinese investment in industries beyond traditional investment sectors such as energy, mining and agriculture, which are already well-explored and currently maturing. New investments in areas where China has relative capabilities, such as logistics and construction, could improve the region's relatively uncompetitive infrastructure. Furthermore, Chinese investment in the industrial sector could also stimulate economic activity, but possibly even more important are the opportunities for cooperation in technology, given China's rapid development in that sector.

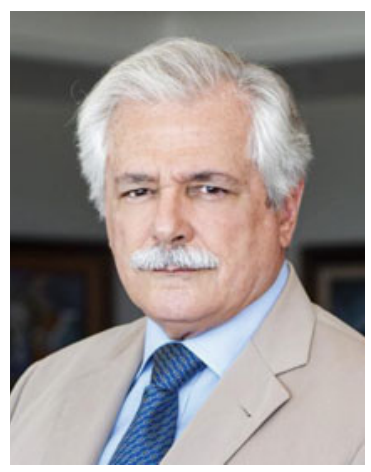

Luiz Augusto de Castro Neves is President of the BrazilChina Business Council; Former Ambassador of Brazil to Japan, China, and Paraguay. At the Ministry of Foreign Affairs, he was Assistant Secretary-General for Foreign Affairs and Director General for the Americas. He held the positions of Deputy Chief of Economic Affairs of the National Security Council Staff and Executive Secretary for Strategic Affairs of the Presidency of the Republic; Former president of CEBRI and current VicePresident Emeritus. He holds a Master's Degree in Economics from University College, University of London. 


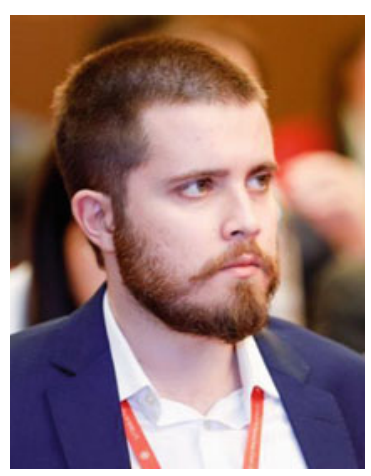

Tulio Cariello is Director of Content and Research of the Brazil-China Business Council. He is the author of several publications on Chinese investment in Brazil, including "Chinese investments in Brazil (2018): the Brazilian framework in a global perspective". He is also the author of studies about opportunities for trade and investments in China. Cariello participated in the Young Sinologists program at Chongqing Normal University in China in 2018. He graduated in International Relations from the Institute of International Relations at the Pontifical Catholic University of Rio de Janeiro.

Open Access This chapter is licensed under the terms of the Creative Commons AttributionNonCommercial-NoDerivatives 4.0 International License (http://creativecommons.org/licenses/bync-nd/4.0/), which permits any noncommercial use, sharing, distribution and reproduction in any medium or format, as long as you give appropriate credit to the original author(s) and the source, provide a link to the Creative Commons license and indicate if you modified the licensed material. You do not have permission under this license to share adapted material derived from this chapter or parts of it.

The images or other third party material in this chapter are included in the chapter's Creative Commons license, unless indicated otherwise in a credit line to the material. If material is not included in the chapter's Creative Commons license and your intended use is not permitted by statutory regulation or exceeds the permitted use, you will need to obtain permission directly from the copyright holder.

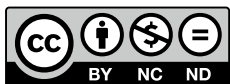

